\title{
Metabolic and renal changes in two athletes during a world 24 hour relay record performance
}

\author{
R.A. Irving, BVetMed, Msc, T.D. Noakes, MA FACSM, R. van Zyl Smit, MD, FCP, MRCP
}

MRC/UCT Bioenergetics of Exercise Research Unit, Departments of Physiology and Medicine, University of Cape Town Medical School and Groote Schuur Hospital, South Africa

\begin{abstract}
Metabolic parameters and renal function were studied in two subjects before, during and after they established a world two-man 24 hour relay record. During the race, the athletes expended an estimated 37.747 and $42.880 \mathrm{~kJ}$ running at 54 and 61 per cent of maximum oxygen consumption $\left(\mathrm{VO}_{2}\right.$ max). Rectal temperatures reached maxima of 38.6 and $39.2^{\circ} \mathrm{C}$ respectively during the race.

Serum free fatty acid levels peaked at 2108 and $1875 \mu \mathrm{mol}$ $\mathrm{ml}^{-1}$ after 24 hours; blood glucose levels varied from 4.3-6.5 and 4.9-8.5 mmol. $\mathrm{I}^{-1}$ respectively. Plasma insulin levels fell from 42.9 and $22.7 \mu \mathrm{U} \cdot \mathrm{ml}^{-1}$ to $11.5 \mu \mathrm{U} \cdot \mathrm{ml}^{-1}$. Plasma urea, creatinine, $\beta_{2}$-microglobulin and $C$-reactive protein concentrations were elevated at the end of the race (to 9.0 and $8.0 \mathrm{mmol} .1^{-1}, 119$ and $102 \mu \mathrm{mol}^{-1}, 3.508$ and 3203 $\mu \mathrm{g} .1^{-1}$ and 2.7 and $3.9 \mathrm{mg}$ per cent respectively). Plasma osmolality was altered from 293 and 304 to 302 and 280 mosmol. $\mathrm{Kg}^{-1}$ during the race but increased to 312 and 318 mosmol. $\mathrm{Kg}^{-1}$ the following day probably due to intercompartmental fluid shifts.
\end{abstract}

Plasma creatinine concentration was increased by 38 and 26 per cent due to reduced urinary excretion. Urine flow rate increased 40 and 123 per cent respectively during the race, but creatinine clearance decreased by 38 and 40 per cent. Urine osmolality decreased by 38 and 65 per cent and osmolal clearance decreased by 15 and 16 per cent respectively. Urine sodium excretion was greatly reduced ( 85 and 90 per cent) on the post-race days (by 88 and 92 per cent on day 2).

Both urine total protein and $\beta_{2}$-microglobulin excretion increased during the race (by 89 and 35 per cent and by 334 and 136 per cent respectively), but owing to the increased $\beta_{2}$-microglobulin production renal clearance was unaltered. The changes in renal function were temporary and some aspects of renal tubular function were enhanced during the post-race days.

We conclude that, although C-reactive protein concentrations increased sooner and were higher than other shorter events and although creatinine, urine excretion and urine osmolality decreased markedly, the intermittent nature of the event, the mild environmental conditions, the moderate percentage of $\mathrm{VO}_{2}$ max maintained by the well conditioned subjects and a high fluid intake enabled a rapid return to normality and indeed to enhanced renal tubular function. The only moderate increases in body temperature would be due to the same factors.

Keywords: Renal function, ultra-distance running, rectal temperature, $\mathrm{VO}_{2} \max$

Address for correspondence: Professor T.D. Noakes, Sports Science Centre, University of Cape Town Medical School, Observatory, 7925 Cape Town, South Africa

(C) 1989 Butterworth \& Co (Publishers) Ltd 0306-3674/89/040227-06 $\$ 03.00$

\section{Introduction}

Numerous studies have reported physiological and biochemical changes during running events of one to four hours duration either on a single day or on consecutive days $\mathrm{s}^{1,2}$, or of running events lasting up to 11 hours $^{3-7}$. Few have studied running ${ }^{8-12}$ or cycling ${ }^{13}$ events lasting up to 24 hours.

In view of the relative paucity of this information, we chose to study two men who ran one mile at a time, sequentially in relay for a 24 hour period during which they set a new world record for this event. We studied changes in a variety of physiological and biochemical variables at regular intervals during the 24 hour period in order to establish possible factors determining success in this event.

\section{Materials and methods}

The subjects for this study were experienced runners, each having run more than $5042.2 \mathrm{~km}$ standard marathons. Both have completed the $90 \mathrm{~km}$ Comrades ultramarathon on at least six occasions with best times of $5 \mathrm{~h} 58 \mathrm{~min}$ and $6 \mathrm{~h} 30 \mathrm{~min}$. Prior to the relay race, which was run on a tartan track under very mild environmental conditions (range of Wet Bulb Globe Temperature Index $=9.7-16.3^{\circ} \mathrm{C}$ ), the athletes reported to the laboratory for the measurement of maximum oxygen consumption and running economy during submaximal exercise by methods previously described $^{14}$.

Measurements of renal function, daily blood and 24 hour urine collections were made for two days before and for two days after the 24 hours of the race. During the race, the athletes were weighed every hour on an electronic scale (Vogel and Halke, Hamburg, West Germany) and their rectal temperatures were measured. Blood samples were drawn by venepuncture every three hours with minimal stasis and in a consistent posture. All urine passed was collected, the volumes measured and aliquots stored frozen for subsequent anaylsis. Plasma and urine electrolytes were determined by flame photometry (model I.L. 435), creatinine by the Jaffee reaction measured on a model I.L. 919 spectrophotometer, and osmolality by the depression of freezing point using an automatic osmometer (Gonotec: Osmomat 030).

Serum C-reactive protein (CRP) concentration was measured by the Laurell Rocket Electrophoretic assay, 
Table 1. Physiological and performance profile of the two subjects

\begin{tabular}{lcc}
\hline Athlete & $\mathrm{BM}$ & $\mathrm{GD}$ \\
Age $(\mathrm{yr})$ & 37 & 28 \\
Height $(\mathrm{cm})$ & 175 & 179 \\
Weight $(\mathrm{kg})$ & 70.3 & 70.9 \\
$\mathrm{VO}_{2} \mathrm{max}\left(\mathrm{ml} \mathrm{O}_{2} \mathrm{~kg}^{-1} \mathrm{~min}^{-1}\right)$ & 66.8 & 68.9 \\
Maximum heart rate $\left(\right.$ beats $\left.\mathrm{min}^{-1}\right)$ & 185 & 187 \\
$\mathrm{Peak}_{\text {treadmill velocity }\left(\mathrm{km} \mathrm{hr}^{-1}\right)}$ & 23 & 23 \\
$\mathrm{O}_{2}$ cost at race pace $\left(13.48 \mathrm{~km}_{\mathrm{hr}} \mathrm{hr}^{-1}\right)$ & 36.3 & 42.0 \\
$\quad\left(\mathrm{ml} \mathrm{O}_{2} \mathrm{~kg}^{-1}\right.$ min $\left.^{-1}\right)$ & $54 \%$ & $61 \%$ \\
Race pace as $\% \mathrm{VO}_{2}$ max $(\%)$ & 36.747 & 42.880 \\
Estimated $\mathrm{kJ}$ expended & 18 & 11 \\
Number of years of running & $2: 22: 51$ & $2: 26: 20$ \\
Best marathon time $: \mathrm{h}: \min : \mathrm{s}$ & & \\
\hline
\end{tabular}

$\beta_{2}$-microglobulin levels were measured by the Phadebas $\beta_{2}$-micro radioimmunoassay test, and total urine proteins by the Biuret method measured on a spectrophotometer. Plasma glucose was measured by the glucose oxidase method (Beckman Glucose Analyzer II, Beckman Instruments, Fullerton, CA, USA). Serum free fatty acids were determined either by chromatography or colourimetrically by a modification of the technique of Noma et al. ${ }^{15}$. Serum immunoreactive insulin levels were measured by radioimmunoassay kit (Ref-Insik-1).

All food and drink consumed over the 24 hours was also recorded. The 24 hourly rate of creatinine and urea production were calculated by summing the 24 hour urinary excretion rate for these substances with the additional amounts retained in the body during the same period on the assumption that the volumes of the creatinine and urea spaces are 60 per cent of the body weight on that day ${ }^{16}$. Renal $\beta_{2}$-microglobulin clearance rate was calculated in $\mu \mathrm{l}$.min ${ }^{1}$ using the formula $^{17}$ :

Urine concentration $\left(\mu \mathrm{g} \cdot \mathrm{ml}^{-1}\right) \times$ urine flow rate $\left(\mathrm{ml} . \mathrm{min}^{-1}\right)$

Plasma concentration $\left(\mu \mathrm{g} \cdot \mathrm{ml}^{-1}\right)$

\section{Results}

\section{Physiological and performance profile of the two subjects}

The heights, weights, maximum rates of oxygen consumption $\left(\mathrm{VO}_{2}\right.$ max), maximum heart rates, peak treadmill running velocities and best marathon performances of both subjects were quite similar, but runner $\mathrm{BM}$ was more economical as measured by the oxygen cost and the $\% \mathrm{VO}_{2}$ max at race pace than was runner GD. During the race, the runners ran at 54 and 61 per cent of $\mathrm{VO}_{2}$ max, and expended an estimated 37747 and $42880 \mathrm{~kJ}$ respectively (Table 1). Their mean running speed was 6.7 and $6.8 \mathrm{~min} . \mathrm{mile}^{-1}$ respectively, with a range of $5 \mathrm{~min} 45 \mathrm{~s}$ to $9 \mathrm{~min} 25 \mathrm{~s}$ and $5 \mathrm{~min} 30 \mathrm{~s}$ to $9 \mathrm{~min} 23 \mathrm{~s}$. The runners ran their tastest for miles and 198 and 199, and their slowest were the last two miles. Their running speed was approximately constant throughout the remainder of the race.

\section{Blood biochemical changes}

Blood glucose levels varied from 4.3 and 4.9 to 6.5 and $8.5 \mathrm{mmol} .1^{-1}$ during the race; plasma insulin levels fell
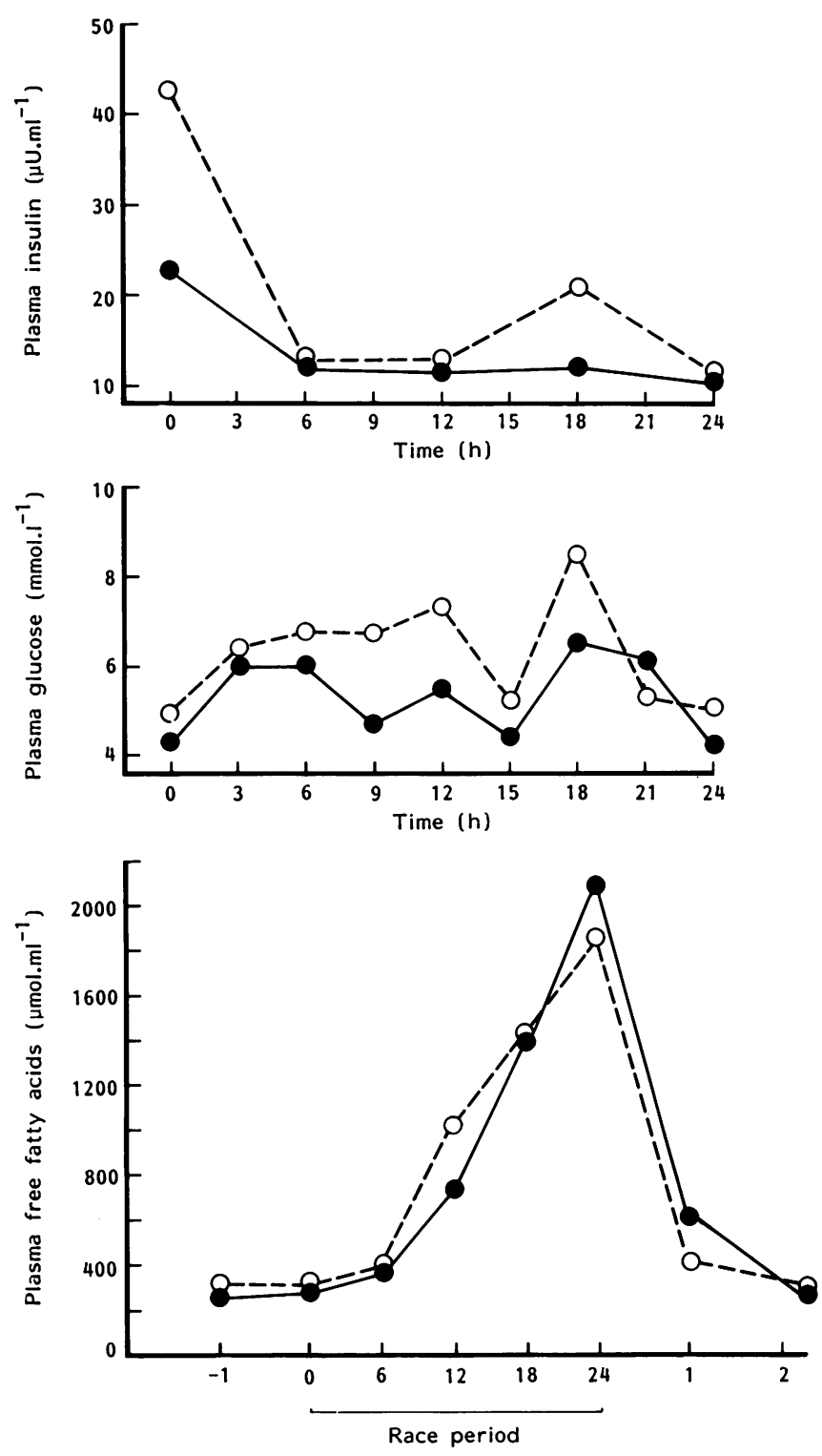

Figure 1. Plasma glucose and insulin concentrations over the race period and plasma free fatty acid concentrations from day -1 to day +2 .

$-\bullet$ indicates Runner BM and O-_--o Runner GD.

from 42.9 and $22.7 \mu U \cdot \mathrm{ml}^{-1}$ to 10.1 and $11.5 \mu \mathrm{U} \cdot \mathrm{ml}^{-1}$ at six hours, whilst plasma free fatty acid levels rose progressively during the race reaching peak levels of 2108 and $1875 \mu \mathrm{mol} . \mathrm{ml}^{-1}$ at 24 hours (Figure 1).

Plasma urea, creatinine, $B_{2}$-microglobulin and $C$ reactive protein concentrations rose during the race (Figure 2); the latter reached peak levels of 2.7 and 3.9 $\mathrm{mg} \%$ on the post-race day. Plasma osmolality decreased in one runner during the race and was elevated in both on the post-race day (Figure 2).

Measured urine excretion and calculated production rates (Figure 3) showed that the increase in plasma creatinine concentrations was mainly due to a reduced rate of creatinine excretion whereas the increase in serum urea concentration was due to both an increased rate of production (a 109 and two per cent increase) and a reduced rate of renal excretion (an 18 and 26 per cent decrease). 

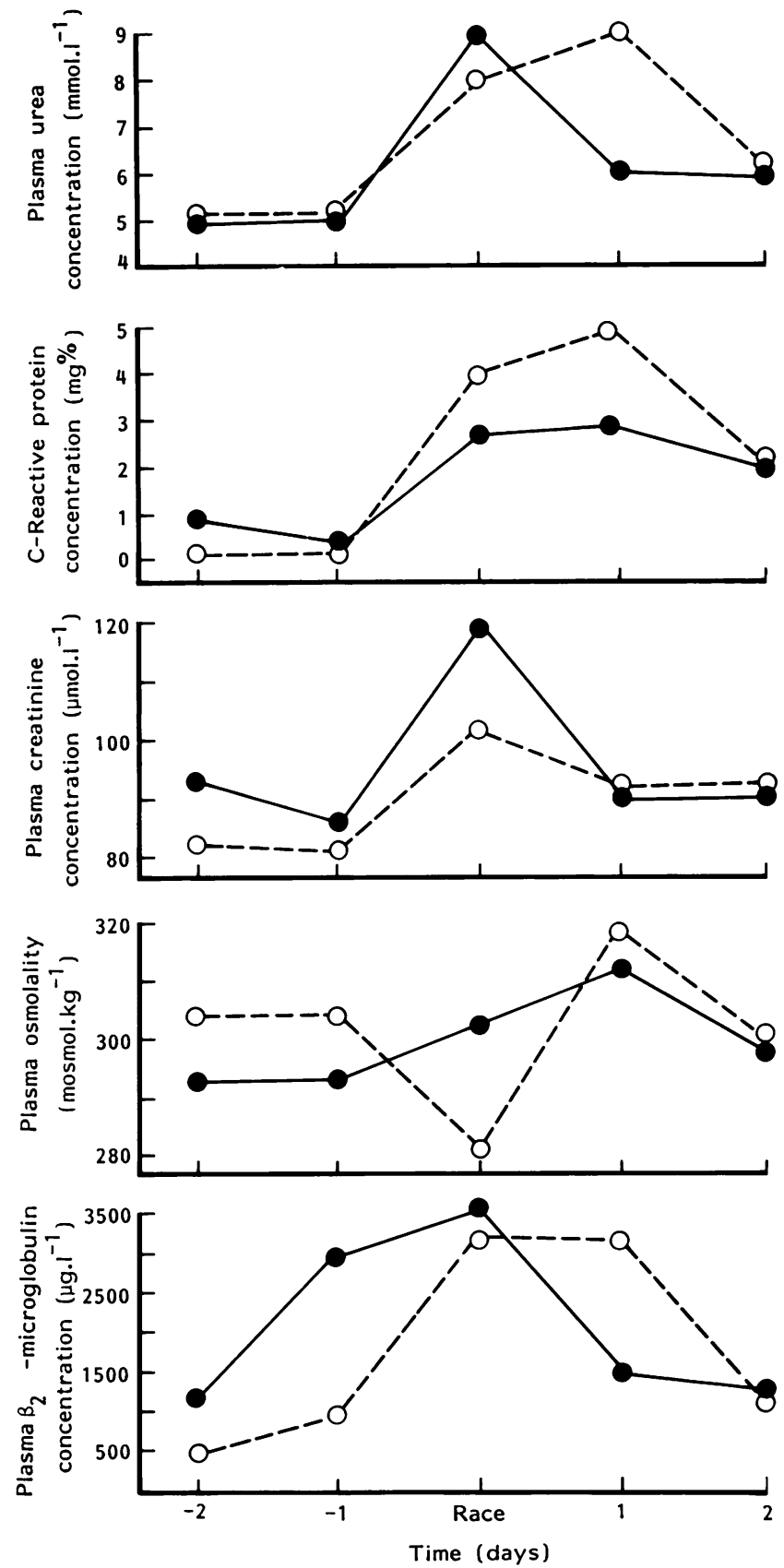

Figure 2. Plasma urea, $C$-reactive protein, creatinine and $\beta_{2}$ microglobulin concentrations and plasma osmolality over the study period.

Key as in Figure 1.

\section{Rectal temperatures and body weight changes during the race}

During the race, the athletes' rectal temperatures rose only moderately to a maximum of $38.6^{\circ} \mathrm{C}$ at three hours for $\mathrm{BM}$ and $39.2^{\circ} \mathrm{C}$ at eight hours for GD. At the end of the race, body temperatures were $37.5^{\circ} \mathrm{C}$ and $38.3^{\circ} \mathrm{C}$ respectively. By this time the runners had lost a mean 3 and $3.7 \mathrm{~kg}$ (4.3 and 5.2 per cent of their initial body weights). Rates of water loss corrected for fluid ingested and an expected rate of energy consumption of $1659 \mathrm{~kJ} \mathrm{hr}^{-1}$ (equivalent to $49 \mathrm{~g}$ carbohydrate and $23 \mathrm{~g}$ fats at an average RER of 0.85 ) were 736 and 623 $\mathrm{ml} . \mathrm{hr}^{-1}$.
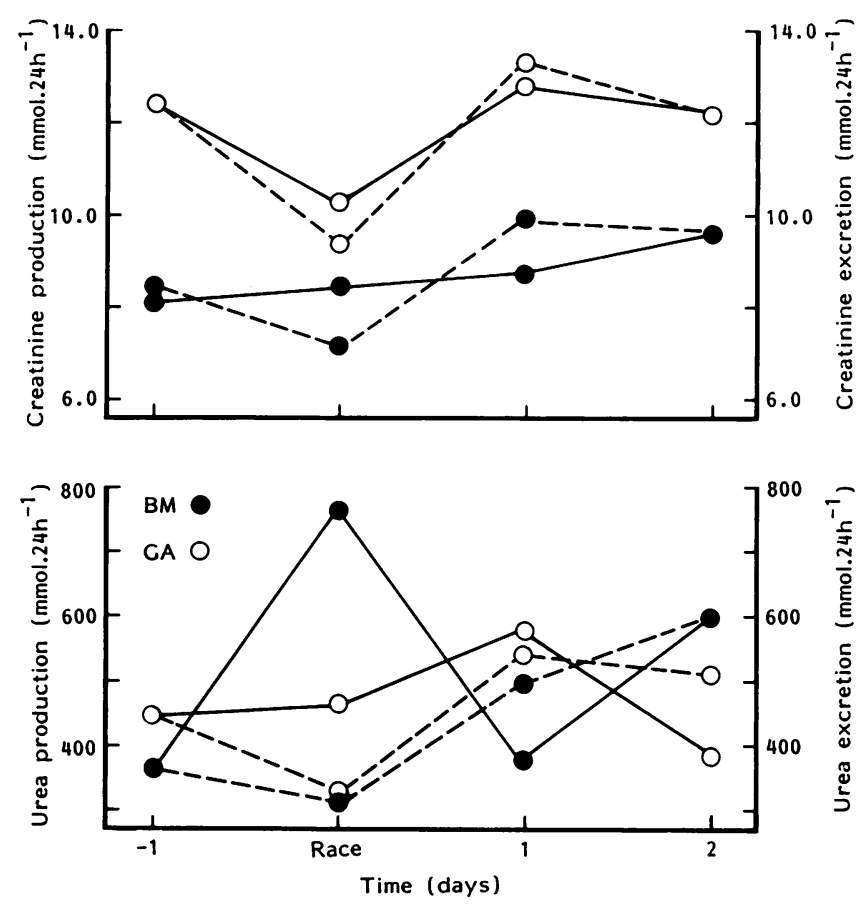

Figure 3. Urinary creatinine and urea production and excretion over the period day -1 to day +2 .

$\bullet-\bullet$ and $\bigcirc-O$ indicate production figures for $\mathrm{BM}$ and GD respectively while $\bullet----\bullet$ and $\mathrm{O}_{----} \mathrm{O}$ indicate excretion figures.

\section{Renal function}

Urine flow rate increased during the race with urine volume increasing from 1820 and 2000 to 2550 and 4455 $\mathrm{ml} .24 \mathrm{hr}^{-1}$ respectively. In spite of the increased urine flow rate, creatinine clearance dropped 38 and 40 per cent from 67.6 and $106.3 \mathrm{ml}$.min to 41.7 and 63.7 $\mathrm{ml} . \mathrm{min}^{-1}$ during the race (Figure 4). Urine osmolality decreased concomitantly to 298 and 184 mosmol. $\mathrm{kg}^{-1}$, 38 and 65 per cent of the pre-race figure (Figure 4), but there was a rapid return to higher than normal values on the two post-race days. Renal osmolal clearance fell during the race and remained low for the 48 hours thereafter (Figure 4).

Unexpectedly, there was no decreased urine sodium excretion by the kidneys during the race period (Figure 5), but the sodium excretion fell to 14 and 16 per cent of pre-race values on day 1 and to 12 and 8 per cent on day 2 . There was also a lesser reduction in potassium excretion on these days (Figure 5), while urea excretion which had decreased by 18 and 26 per cent on the race day, was increased on post-race days 1 and 2 (Figure 3 ).

A proteinuria occurred during the race (Figure 6), with total protein excretion increasing 136 and 35 per

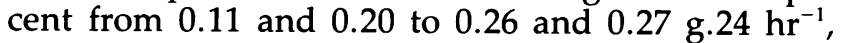
while $B_{2}$-microglobulin excretion increased 334 and 89 per cent from 1722 and 4026 to 7482 and $7627 \mu \mathrm{g} .24$ $\mathrm{hr}^{-1}$. Reduced total protein excretion and $\beta_{2}$-microglobulin excretion and clearance rates were noted on the subsequent two days (Figure 6).

\section{Discussion}

The previous world record for this two-man 24 hour relay was 193 miles 1605 yards (301 km $268 \mathrm{~m})$, a dis- 

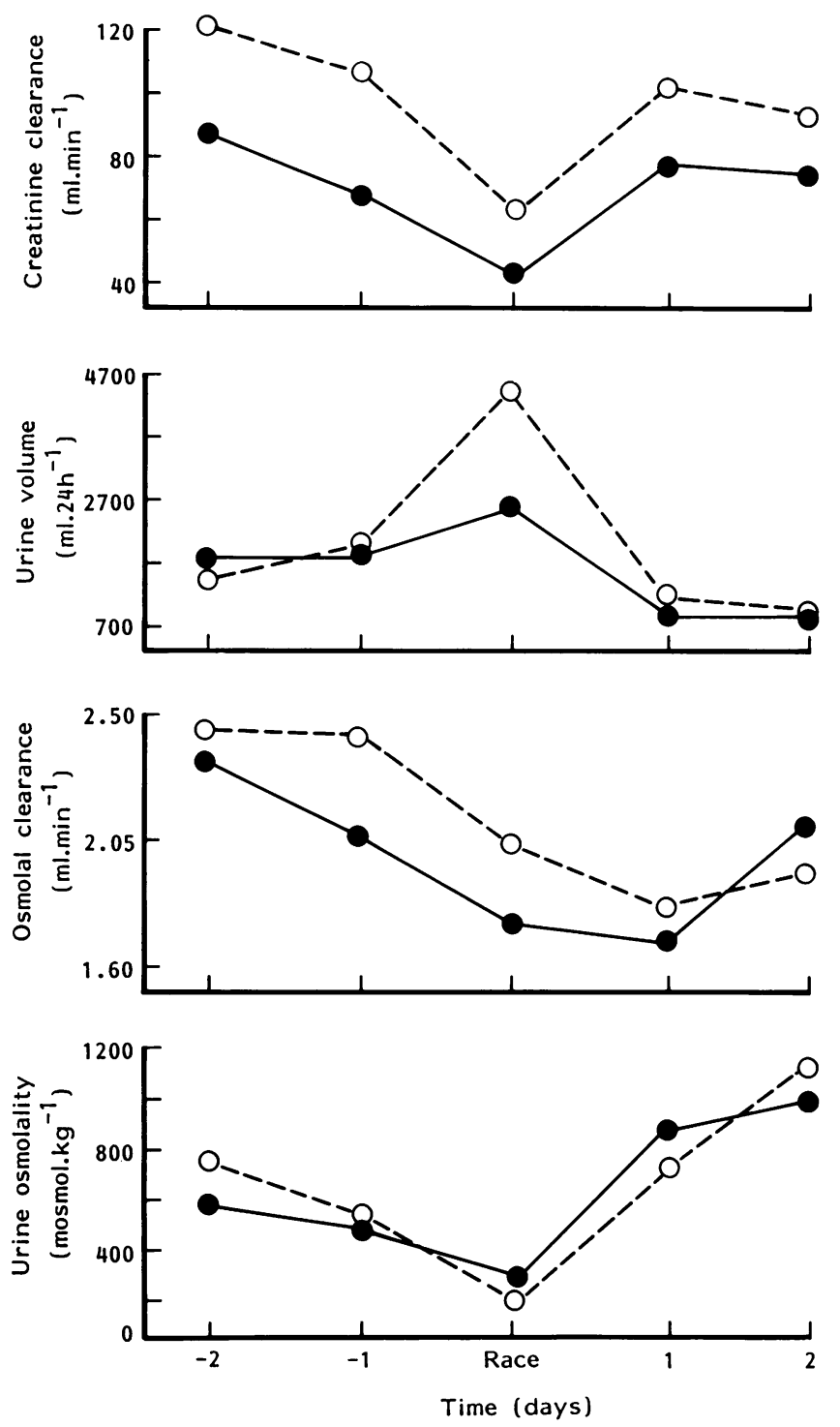

Figure 4. Creatinine clearances, urine volumes, osmolal clearances and urine osmolality over the study period. Key as in Figure 1.

tance which was exceeded by the runners who ran 201 miles (321 km $600 \mathrm{~m})$.

\section{Metabolic and thermoregulatory changes}

Metabolic changes during the race were the same as measured during shorter distance races. Serum free fatty acid levels rose progressively during the run reaching values of 2108 and $1875 \mu \mathrm{mol} . \mathrm{m}^{\prime}$ after 24 hours. Serum insulin levels fell despite a regular intake of food which was not the case after a $100 \mathrm{~km}$ run $^{18}$. Blood glucose levels were elevated for the duration of the race (Figure 1). These changes are essentially similar to those measured after continuous running in marathon ${ }^{19}$ and ultramarathon races $^{-18,19}$ and other intermittent events lasting 24 hours 9.

Mean serum C-reactive protein concentration rose during the race reaching peaks of 2.7 and $3.9 \mathrm{mg} \%$ on day 1 (Figure 2) compared to means of $2.7 \mathrm{mg} \%$ after an $88 \mathrm{~km}$ race ${ }^{20}$, and of $1.9 \mathrm{mg}$ per cent recorded after a $42 \mathrm{~km}$ marathon $^{21}$. Higher serum C-reactive protein concentration may indicate more severe muscle damage than
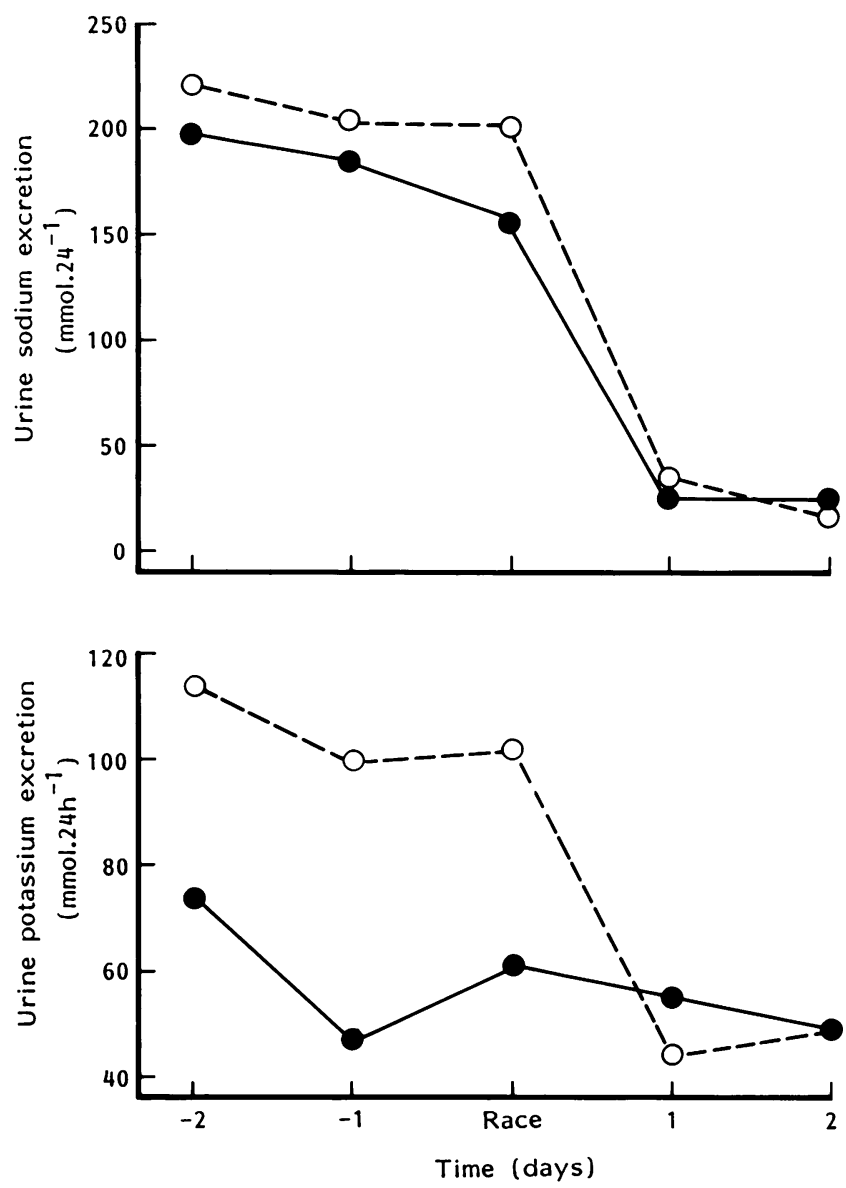

Figure 5. Daily urinary sodium and potassium excretion over the study period.

Key as in Figure 1.

occurs during shorter duration continuous running. Because of the duration of this race, the CRP levels become elevated much sooner than in the studies of the above authors.

Body temperatures rose only moderately during the race and were lower than temperatures of $38.5-39.5^{\circ} \mathrm{C}$ measured after 42 and $56 \mathrm{~km}$ races $^{20,22}$. The lower temperatures would probably be explained by the intermittent nature of the exercise, the lower $\% \mathrm{VO}_{2} \max$ sustained by the subjects during the race, and the moderate environmental conditions.

\section{Changes in renal function}

Creatinine and osmolal clearances fell markedly during the run in spite of increased urine flow rates (Figure 4). Exercise usually exerts an anti-diuretic effect ${ }^{23}$ even under conditions of hyperhydration ${ }^{2+}$. Although creatinine clearance commonly falls during exercise, this decrease can be inhibited by increased hydration, ${ }^{23}$ and our previous studies showed that creatinine clearance can be maintained when measured over the duration of a marathon ${ }^{21}$ or ultramarathon races of up to $90 \mathrm{~km}^{25,26}$. It would seem that, in spite of adequate hydration and an increased urine flow rate, the very prolonged nature of this activity and the extra distance covered were the factors determining the fall in creatinine and osmolal clearances. These changes were however transient, with return to normal renal function within 24 hours after the race. 

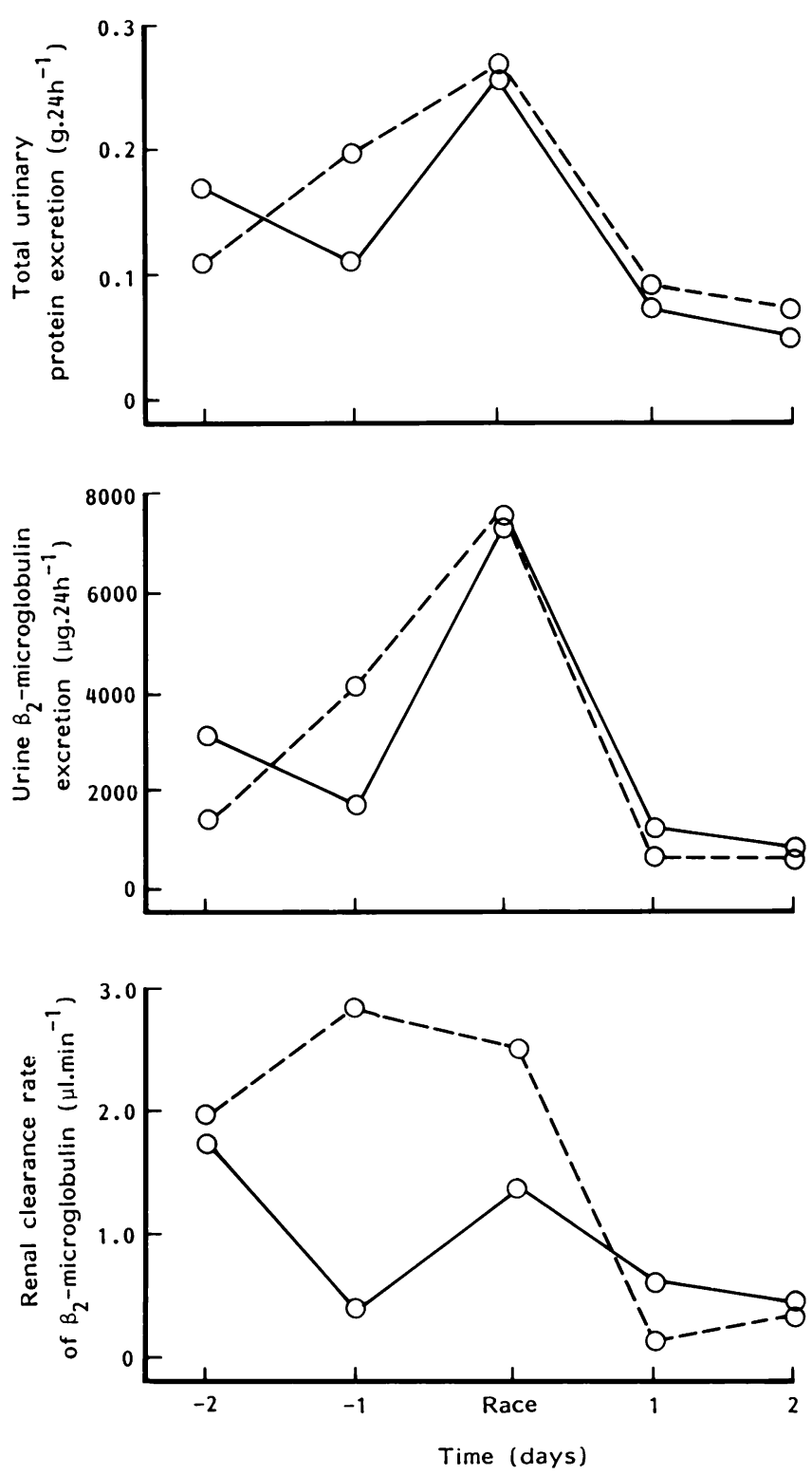

Figure 6. Daily urinary total protein and $B_{2}$-microglobulin excretion and renal clearance rates of $B_{2}$-microglobulin. Key as in Figure 1.

The increases in plasma urea (Figure 2) were not only caused by decreased urine secretion, but also by increased production (Figure 3), probably due to the increased use of amino acids as a substrate for gluconeogenesis ${ }^{27}$.

Previous reports have shown that a proteinuria develops during prolonged running ${ }^{17,21}$ associated with an increased glomerular permeability. After shortterm exhaustive exercise, renal tubular impairment can occur ${ }^{24}$. Assuming that the increased total urinary protein excretion after exercise comprises mainly albu$\min ^{28}$, our results would also indicate only an increase in glomerular permeability (Figure 6).

Owing to the marked increase in plasma $\beta_{2}$-microglobulin levels (Figure 2), at least part of the increased urine $\beta_{2}$-microglobulin excretion may have resulted from saturation of the tubular reabsorption process, rather than from tubular dysfunction as is indicated by the renal clearance rate (Figure 6). The rapid return of renal tubular reabsorption capacity during the subsequent days after the race indicates a rapid normalization of renal tubular function (Figure 6). Indeed, the excretion and clearance values recorded (Figure 6), indicate that renal tubular function was enhanced during the two post-race days.

Intercompartmental fluid shifts have been shown to occur after long-distance running ${ }^{25,29,30}$, with an initial influx of protein into the vascular compartment forming an osmotic basis for the retention of water in the compartment ${ }^{25,30}$. Despite moderately high rates of water loss (means of 1472 and $1246 \mathrm{ml} \mathrm{hr}^{-1}$ and weight losses of 4.3 and 5.2 per cent), plasma osmolality decreased in one runner (GD) during the race (Figure 2), suggesting that plasma volume was increased as has been reported previously in long-distance runners ${ }^{25,31}$.

Plasma sodium concentrations remained consistent for the entire experimental period in spite of increased tubular sodium reabsorption as indicated by the redution in urinary sodium excretion on the post-race days (Figure 5). The decreased rate of sodium excretion was still present on the second post-race day. Renal sodium conservation therefore persisted for longer than has been reported after marathon and ultramarathon races $21,25,26$.

In summary, in spite of jointly running a world record distance of $321.6 \mathrm{~km}$ in less than 24 hours during which each runner expended an average of $40.313 \mathrm{~kJ}$, metabolic and renal changes were adaptive. Serum blood glucose levels remained within normal levels, plasma insulin levels were decreased and there was a steady increase in plasma free fatty acid levels. The increases in plasma urea and $\beta_{2}$-microglobulin concentrations were due mainly to increased production.

However, in spite of an increase in urine output, creatinine and urea excretion were decreased as was creatinine clearance. These levels returned to normal on the post-race day. Urinary total protein and $\beta_{2}$-microglobulin excretion were increased, but as the renal $\beta_{2}$-microglobulin clearance rate was unchanged, only an increase in glomerular permeability was noted. The clearance was decreased on the post-race days possibly indicating enhanced renal tubular funtion. Osmolal clearance and urine osmolality were decreased during the race, but the latter increased during the post-race days to above pre-race levels in both runners, in spite of a reduced urine sodium excretion on those days.

We conclude that, owing to pre-race conditioning, the low percentage of $\mathrm{VO}_{2}$ max utilized, the intermittent nature of the event which allowed time for adequate fluid and calorie replacement; and the very mild environmental conditions, renal and metabolic function remained adequate to cope with the stress of this particular event.

\section{Acknowledgements}

This work was supported by the Medical Research Council of South Africa, the Harry Crossley and Nellie Atkinson Research Funds of the University of Cape Town, and the South African Association for Sports Science, Physical Education and Recreation.

Sincere thanks are due to the subjects who participated and to F. Abrahams, P.J. Camacho, M.J. Levey and $\mathrm{N}$. Allie for technical assistance. 


\section{References}

1 Dressendorfer, R.H., Wade, C.E. and Ezra, A. Development of pseudonaemia in marathon runners during a 20-day road race JAMA 1981, 246, 1215-1218

2 Maron, M.B. and Horvath, S.M. The marathon: a history and review of the literature Med Sci Sports 1978, 10, $137-150$

3 Dancaster, C.P. and Whereat, S.J. Fluid and electrolvte balance during the Comrades Marathon $S$ Afr Med J $1971,45,147-150$

4 Dancaster, C.P. and Whereat, S.J. Renal function in marathon runners S Afr Med I 1971, 45, 547-551

5 Dancaster, C.P., Duckworth, W.C. and Roper, C.J. Nephropathy in marathon runners $S$ Afr Med J1969, 43 , 758-759

6 McKechnie, J.K., Leary, W.P. and Joubert, S.M. Some electrocardiographic and biochemical changes recorded in marathon runners $S$ Afr Med J 1967, 13, 722 725

7 McKechnie, J.K., Leary, W.P. and Noakes, T.D. Metabolic responses to a $90 \mathrm{~km}$ running race $S$ Afr Med J 1982, 61, 482-484

8 Davies, C.T.M. and Thompson, M.W. Estimated aerobic performances and energy cost of severe exercise of 24 h duration Ergonomics 1979, 22, 1249-1255

9 Houston, M., Green, H., Thomson, J. and Reid, P. The response of oxygen consumption, body temperature, blood substrates and serum enzymes to intermittent heavy work performed over twenty-four hours Eur J Appl Physiol 1978, 39, 145-154

10 Lloyd, E.L.L., Henderson, W., Covell, B. and Bryce, G.R. Factors affecting performance during an endurance relay $\mathrm{Br}$ J Sports Med 1977, 11, 138-142

11 Noakes, T.D. and Carter, J.W. Biochemical parameters in athletes before and after having run 160 kilometers $S$ Afr Med I 1976, 50, 1562-1566

12 O'Hara, W.J., Allen, C., Shephard, R.J. and Gill, J.W. La Tulippe - A case study of a hundred and sixty kilometre runner Br J Sports Med 1977, 11, 83-87

13 White, J.A., Ward, C. and Nelson, H. Ergogenic demands of a 24 hour cycling event Br J Sports Med 1984 $18,165-171$

14 Scrimgeour, A.G., Noakes, T.D., Adams, B. and Myburgh, $\mathrm{K}$. The influence of weekly training distance on fractional utilization of maximum aerobic capacity in marathon and ultramarathon runners Eur I Appl Physiol 1986, 55, 202-209

15 Noma, A., Okabe, H. and Kita, M. A new colorimetric microdetermination of free fatty acids in serum Clin Chim Acta 1973, 43, 317-320

16 Peters, I.P., and Van Slyke, D.D. Quantitative clinical chemistry. Interpretations Baltimore, The Williams and Wilkins Co. Vol 1, 1946

17 Poortmanns, J. and Haralambie, G. Biochemical changes in a $100 \mathrm{~km}$ run. Proteins in serum and urine Eur I Appl Physiol 1979, 40, 245-254

18 Keul, J., Kohler, B., von Glutz, G., Luthi, U., Berg, A. and Howald, $\mathrm{H}$. Biochemical changes in a $100 \mathrm{~km}$ run: Carbohydrates, lipids and hormones in serum Eur J Appl Physiol 1981, 47, 181-189

19 Noakes, T.D., Lambert, V.E., Lambert, M.I., McArthur, P., Myburgh, K.H. and Benade, A.J.S. Carbohydrate ingestion and muscle glycogen utilization during marathon and ultra-marathon racing Eur J Appl Physiol (in press) 1988

20 Strachan, A.F., Noakes, T.D., Kotzenberg, G., Nel, A.E. and De Beer, F.C. C Reactive protein concentrations during long distance running $B r$ Med J 1984, 289, 1249-1251

21 Irving, R.A., Noakes, T.D., Irving, G.A. and Van Zylsmit, R. The immediate and delayed effects of marathon running in renal function J Urol 1986, 136, $1176-1180$

22 Noakes, T.D., Adams, B.A., Myburgh, K.H., Lotz, T. and Nathan, $M$. The danger of an inadequate water intake during prolonged exercise. A novel concept revisited Eur I Appl Physiol 1988, 57, 210-219

23 Castenfors, J. Renal function during exercise Acta Physiol Scand 1967, 70, (Suppl 293), 1-44

24 Poortmans, J. and Vancalk, B. Renal glomerular and tubular impairment during strenuous exercise in young women Eur J Clin Invest 1978, 8, 175-178

25 Irving, R.A., Noakes, T.D., Burger, S.C., Myburgh, K.H., Querido, D. and Van Zyl-Smit, R. Plasma volume and renal function during and after ultramarathon running Med. Sci. Sports. Exer. (in press) 1989

26 Irving, R.A., Noakes, T.D., Raine, R. and Van ZylSmit, R. Transient oliguric renal failure after a $90 \mathrm{~km}$ ultramarathon running race Med. Sci. Sports. Exer. (in press) 1989

27 Decombaz, J., Reinhardt, P., Anantharaman, K., von Glutz, G. and Poortmans, J.R. Biochemical changes in a $100 \mathrm{~km}$ run: Free amino acids, urea, and creatinine Eur I Appl Physiol 1979, 41, 61-72

28 Poortmans, J. and Jeanloz, R.W. Quantitative immunological determination of twelve plasma proteins excreted in human urine collected before and after exercise I Clin Invest 1968, 47, 386-393

29 Costill, D.K. Sweating: Its composition and effects on body fluids Ann NY Acad Sci 1977, 301, 160-174

30 Maron, M.B., Horvath, S.M. and Wilkerson, J.E. Acute blood biochemical alterations in response to marathon running Eur J Appl Physiol 1975, 34, 173-181

31 Maron, M.B., Horvath, S.M. and Wilkerson, J.E. Blood biochemical alterations during recovery from competitive marathon running Eur I Appl Physiol 1977, $36,231-238$

32 Noakes, T.D., Goodwin, N, Rayner, B.L., Branken, T. and Taylor, R.K.N. Water intoxication: a possible complications during exercise Med Sci Sports Exerc 1985, 17, 370-375 